\title{
A Regulação Estatal Como Instrumento de Concretização do Direito Fundamental ao Desenvolvimento Econômico: um Contributo da Análise Econômica do Direito
}

\section{The Regulation State As Achievement Instrument of the Fundamental Right to Economic Development: a Contribution of Economic Law Review}

\section{FILIPE LÔBO GOMES}

Graduado em Direito pela Universidade Federal de Alagoas (2003), Especialista em Direito Público pela Faculdade Maurício de Nassau (2006), Mestre em Fundamentos Constitucionais dos Direitos pela Universidade Federal de Alagoas (2006), Doutor em Estado, Regulação e Tributação Indutora pela UFPE (2015), Ex-Procurador-Geral do TJAL, Ex-Assessor de Planejamento do TJAL, Ex-Coordenador Técnico do Gabinete Civil do Governo do Estado de Alagoas, Professor da Faculdade de Direito da Universidade Federal de Alagoas, na disciplina Direito Administrativo, onde exerce a função de Coordenador de Curso. Leciona em cursos de especialização. Atualmente é Assessor Judiciário no Tribunal de Justiça de Alagoas. Tem experiência na área de Direito, com ênfase em Direito Administrativo, Tributário e Constitucional, atuando principalmente nos seguintes temas: regulação, desenvolvimento econômico, infraestrutura, petróleo, análise econômica do direito, governança e processo tributário.

Data da Submissão: 14.10 .2016

Data da Decisão Editorial: 20.10.2016

Data de Comunicação ao Autor: 20.10.2016

RESUMO: 0 texto busca apresentar propostas de reformulação do contexto regulatório nacional diante do instrumental ofertado pela nova economia institucional por meio das concepções do que são os custos de transação, as falhas do mercado e as falhas de governo. A partir desses elementos, propõe-se que se lancem novos olhares sobre a regulação como medida necessária a que o Estado possa internalizar as externalidades e maximizar os benefícios sociais. Assim, busca-se ofertar marcos teóricos para tornar a regulação mais eficiente, sensata e essencial à concretização do direito fundamental ao desenvolvimento econômico.

PALAVRAS-CHAVE: Regulação; análise econômica do Direito; direito fundamental ao desenvolvimento econômico. 
ABSTRACT: The text seeks submit proposals to recast the national regulatory framework on the instruments offered by the new institutional economics through the conceptions of what are the transaction costs, market failures and government failures. From these elements, it is proposed to launch new looks about regulation as a step that the state can internalize the externalities and maximize social benefits. So, this research offers theoretical frameworks to make the most efficient, sensible and essential regulation to the achievement of the fundamental right to economic development.

KEYWORDS: Regulation; economic analysis of Law; fundamental right to economic development.

SUMÁRIO: Introdução; 1 A regulação no âmbito do Direito nacional; 1.1 Preliminar teórica - A diferenciação entre intervenção direta e intervenção indireta do Estado; 1.2 A conformação do termo "regulação"; 1.3 A delegação, a desregulação, a rerregulação, a autorregulação e a regulamentação; 1.40 principal instrumento da regulação no Direito nacional; 2 Um contributo institucional à regulação; 2.1 A perspectiva institucional; 2.2 Propostas de revisão institucional da regulação; Considerações finais; Referências.

\section{INTRODUÇÃO}

O presente texto ${ }^{1}$ tem o objetivo de ofertar soluções institucionais de otimização da regulação. Servirá como norte para o aprofundamento teórico que lançará adiante a análise econômica do Direito dentro da perspectiva da nova economia institucional.

De maneira preambular, consigna-se que a nova economia institucional destaca a importância das instituições diante das variáveis inerentes à conformação do mercado. Ela tem como um de seus principais elementos a análise dos custos de transação e dos efeitos que a racionalidade limitada, as externalidades e o oportunismo podem gerar nas relações econômicas um dos principais objetos da regulação estatal.

A presente análise será embasada na teoria do custo das transações, que está informada pelas obras seminais de Ronald Coase, Oliver Williamson ${ }^{2}$ e Douglass North ${ }^{3}$ sobre o trato de mencionados custos na conformação das organizações e das instituições na economia.

Nesse sentido, o estudo será dirigido ao aprofundamento dos padrões de densificação normativa ${ }^{4}$ necessários a emoldurar a regulação estatal den-

1 Este texto foi apresentado como trabalho avaliativo da disciplina Aspectos Econômicos da Regulação do Doutorado do Programa de Pós-Graduação da Faculdade do Direito do Recife.

2 Cf. NÓBREGA, Marcos. Direito da infraestrutura. São Paulo: Quartier Latin, 2011. p. 103.

3 Cf. VIANNA, Salvador Teixeira Werneck. Desenvolvimento econômico e reformas institucionais no Brasil: considerações sobre a construção interrompida. Tese de doutorado. Rio de Janeiro: Instituto de Economia, Universidade Federal do Rio de Janeiro, 2007. p. 36-39.

4 Sobre a análise da densificação normativa, veja CAVALCANTI, Francisco de Queiroz Bezerra. A reserva de densificação normativa da lei para preservação do princípio da legalidade. In: BRANDÃO, Cláudio; 
tro de uma perspectiva de maximização da eficiência, uma maximização que respeite o quadro jurídico constitucional e a sua orientação no sentido de implementação de direitos fundamentais.

Justifica-se o interesse pela abordagem aqui empreendida diante das mudanças ocorridas no postulado clássico da supremacia do interesse público sobre o privado. Hodiernamente, vê-se o fortalecimento da atuação do Estado em parceria com a iniciativa privada, por meio do que se ousa dizer que não persiste mais a concepção clássica de relação vertical público-privado, mas a de uma relação diagonal, dado ainda persistirem as limitações normativas do Direito administrativo nacional, um Direito administrativo constitucionalizado.

Dentro desse caminho, o Estado se dirige cada vez mais para dividir a absorção do risco de suas atividades ${ }^{5}$, de sorte a incentivar a adesão dos particulares para iniciativas de interesse público voltadas ao desenvolvimento nacional e a minorar os seus custos operacionais.

É dentro desse panorama de renovação da concepção clássica do Estado que se empreenderá uma análise do dínamo dessa nova realidade, a regulação estatal.

Assim, para o cumprimento dos desideratos propostos anteriormente, ver-se-á, no primeiro capítulo, a classificação das formas de intervenção estatal para, depois, avançar sobre a compreensão do termo "regulação" no território nacional. Em seguida, serão adensados os conceitos próximos, derivados e contrapostos ao de regulação, especificando os seus instrumentos de atuação. Será apresentada, ainda, a concepção econômica da regulação, com o fito de facilitar o seu cotejo diante da nova economia institucional.

No segundo capítulo, enveredar-se-á pelo detalhamento das bases da nova economia institucional, de maneira a subsidiar uma análise institucional da regulação estatal. Diante desse substrato teórico, a investigação

CAVALCANTI, Francisco de Queiroz Bezerra; ADEODATO, João Maurício (Coord.). Princípio da legalidade: da dogmática jurídica à teoria do Direito. Rio de Janeiro: Forense, 2009. p. 221-234.

5 Traçando o perfil sobre a minimização do risco, Maria da Glória Garcia pondera: "Com a informação e o conhecimento possíveis e com a consciência de não poder, no momento, aceder a mais, são, então, ponderadas as alternativas e avaliadas as probabilidades. A vontade é exercida correndo-se por seu intermédio o risco relativamente ao que se não sabe. Porque o que é inacessível ao conhecimento só pode ser revelado à vontade, [ ] Daí que, se, no limite do conhecimento que cada um possui, é a ignorância que impera, todos têm que querer. Todos têm de correr riscos. A partilha da ignorância arrasta consigo a partilha da vontade, do poder de querer, bem como a partilha dos riscos. [ ] A renovação da democracia que atualmente tanto se fala deve, por isso, porventura fazer-se pela via da acentuação da cidadania participativa, informada, sabedora, que mais não é do que a via da partilha da responsabilidade social" (GARCIA, Maria da Glória F. P. D. Direito das políticas públicas. Coimbra: Almedina, 2009. p. 240). 
será dirigida à identificação dos principais problemas regulatórios e à subsequente oferta de soluções. Por fim, ofertar-se-á uma nova forma de entender a regulação estatal no âmbito do Estado brasileiro.

Esses são, em síntese, os pontos principais do presente trabalho.

\section{A REGULAÇÃO NO ÂMBITO DO DIREITO NACIONAL}

\subsection{Preliminar teórica - A diferenciação entre Intervenç̃ó direta e Intervenção Indireta do ESTADO}

Eros Grau, empós destacar que a intervenção estatal difere da atuação estatal, pois esta incide sobre todas as atividades econômicas, públicas ou privadas, e aquela exclui os serviços públicos e a sua regulação, classifica as formas de intervenção estatal da seguinte forma: a) intervenção por absorção ou participação; b) intervenção por direção; e c) intervenção por indução.

No primeiro caso, o Estado intervirá no domínio econômico como agente econômico, seja atuando no regime de monopólio - caso de absorção -, seja atuando no regime de competição - caso de participação. Nos outros dois, o Estado intervirá sobre o domínio econômico, regulando as atividades desenvolvidas no mercado. No caso da intervenção por direção ${ }^{6}$, o Estado imporá normas de comportamento obrigatórias, enquanto na intervenção por indução o Estado estimulará o mercado a agir conforme seus interesses ${ }^{7}$.

A seu turno, Francisco Queiroz Bezerra Cavalcanti indica três formas básicas de intervenção estatal na ordem econômica: a) como agente da atividade econômica - a exploração direta da atividade econômica compete ao setor privado, sendo permitido o seu desenvolvimento pelo Estado quando necessário aos imperativos de segurança nacional ou a relevante interesse coletivo, conforme definidos em lei (art. 173 da Constituição Federal de 1988); b) como ente regulador das atividades - possuindo papel importante na proteção dos princípios que pautam a ordem econômica. A regulamen-

6 Em relação a essa forma de intervenção, o que se constata é que, com a redução do papel do Estado como agente da atividade econômica, ela se torna mais relevante para assegurar os princípios básicos, os direitos dos destinatários da atuação dos produtores dos bens e serviços e também dos direitos coletivos e difusos (CAVALCANTI, Francisco Queiroz Bezerra. Reflexões sobre o papel do estado frente à atividade econômica. Revista trimestral de Direito Público, n. 20, p. 73, 1997).

7 GRAU, Eros Roberto. A ordem econômica na Constituição de 1988 (interpretação e crítica). 15. ed. rev. e atual. São Paulo: Malheiros, 2012. p. 90-91; 143-142. 
tação não tende a sofrer redução, mesmo com a nova postura (neoliberal) do Estado, ganhando realce a sua missão de fiscalizar as atividades econômicas exercidas pelo setor privado; c) como agente indutor - nesse campo, pode valer-se da política fiscal, com a concessão de incentivos setoriais ou regionais, utilizando maior ou menor incidência da carga tributária como mecanismo redutor de custos e estimulador de atividades econômicas ${ }^{8}$.

Pois bem, diante das exposições trazidas anteriormente, tem-se que, quer se opte por diferençar os termos "intervenção" e "autuação", quer se opte por verificar que o termo "intervenção" engloba a realidade econômica pública e privada, a questão principal é a de se saber se a intervenção se dará de forma direta ou indireta, no que as duas formas de se classificar apresentam uma certa similitude.

Dessa forma, entende-se que o Texto Constitucional quis deixar claro esse direcionamento, porquanto vaza em seu art. 173: "Ressalvados os casos previstos nesta Constituição, a exploração direta de atividade econômica pelo Estado só será permitida quando necessária aos imperativos da segurança nacional ou a relevante interesse coletivo, conforme definidos em lei".

Nesse pensar, a orientação dessa explanação será orientada pelo caráter direto ou indireto da intervenção do Estado na atividade econômica, entendida esta em seu sentido amplo, regedor da esfera pública ou privada.

Entretanto, deve-se alertar para o fortalecimento do intervencionismo indireto estatal, principalmente com o fortalecimento do que se convenciona chamar de Estado Regulador.

Com efeito, o intervencionismo indireto não trata mais da assunção pelo Estado da atividade econômica em si (intervencionismo direto), mas de sua concreta atuação de fomento, na regulamentação, no monitoramento, na mediação, na fiscalização, no planejamento, na ordenação da economia. Enfim, cuida-se da atuação estatal fortemente influente (por indução ou coerção) da ação dos atores privados atuantes em um dado segmento da economia ${ }^{9}$.

Pois bem, volvendo-se à análise para o estudo da intervenção, importa detalhar o porquê de o Estado intervir no domínio econômico. Para além da determinação constitucional brasileira, que dedica um título seu à

8 Cf. CAVALCANTI, Francisco Queiroz Bezerra. Reflexões sobre o papel do estado frente à atividade econômica..., cit., p. 70-74.

9 Cf. MARQUES NETO, Floriano Azevedo. A nova regulação estatal e as agências independentes. In: SUNDFELD, Carlos Ari (Coord.). Direito administrativo econômico. 3. tiragem. São Paulo: Malheiros, 2006. p. 72 e ss. 
ordem econômica e financeira, tem-se que a intervenção estatal no domínio econômico se justifica diante de circunstâncias conhecidas como falhas de mercado, impeditivas do desequilíbrio das forças competitivas e que não consigam ser sanadas por meio dos agentes econômicos, ou seja, por sua autorregulação ${ }^{10}$.

Contudo, dentro da conformação constitucional brasileira, deve se ter em vista que a intervenção do Estado na economia tem por norte a promoção do bem-estar, ao lado e a serviço da liberdade, e dos direitos fundamentais. Porém, para que se implemente o cunho prestacional estatal, necessário se ter em mente que a intervenção estatal deve ser sensata ${ }^{11}$, no sentido de garantir a liberdade do mercado para que se capte a renda necessária ao atendimento das demandas sociais, porquanto o bem-estar daí decorrente possui um papel, e esse papel depende da geração de riqueza, porquanto os direitos têm um custo, devendo tal noção fazer parte do conteúdo dos próprios direitos ${ }^{12-13}$.

\subsection{A CONFormação do teRmo "regulação"}

A ideia de regulação vem vazada no Texto Constitucional, no art. 174:

Art. 174. Como agente normativo e regulador da atividade econômica, o Estado exercerá, na forma da lei, as funções de fiscalização, incentivo e planejamento, sendo este determinante para o setor público e indicativo para o setor privado.

10 TAVARES, André Ramos Tavares. A intervenção do Estado no domínio econômico. In: CARDOZO, José Eduardo Martins; QUEIROZ, João Eduardo Lopes; SANTOS, Walquíria Batista dos Santos (Coord.). Direito administrativo econômico. São Paulo: Atlas, 2011. p. 227.

11 A intervenção sensata, na visão de Egon Bockmann Moreira, deve ser "proporcional e razoável ao mercado e aos interesses públicos e provados em jogo. Num sistema capitalista que celebra constitucionalmente a liberdade de iniciativa, a liberdade de empresa e a liberdade de concorrência (Constituição, art. 170), a intervenção do Estado na Economia há de ser necessária, ponderada, excepcional e pontual - com finalidade pública específica" (MOREIRA, Egon Bockmann. O direito administrativo da economia, a ponderação de interesses e o paradigma da intervenção sensata. In CUÉLLAR, Leila; MOREIRA, Egon Bockmann. Estudos de direito econômico. Belo Horizonte: Fórum, 2004. p. 81).

12 Cf. HOLMES, Stephen; SUNSTEIN, Cass R. The cost of rights: Why liberty depends on taxes. New York: w. W. Norton \& Co., 1999, passim. Em sentido análogo: GALDINO, Flávio. Introdução à teoria dos custos dos direitos. Direitos não nascem em árvores. Rio de Janeiro: Lumen Juris, 2005.

13 Segundo André Ramos Tavares: "O desenvolvimento do Estado passa prioritariamente pelo desenvolvimento do homem, de seu cidadão, de seus direitos fundamentais. Sem ele, o mero avanço econômico pouco significará, ou fará sentido para poucos. Assim, independentemente do conceito que determinada atitude possa ocupar nas teorias econômicas, ela poderá ser adotada se puder ser utilizada como instrumento para alcançar mencionado desenvolvimento. Portanto, a intervenção do Estado, sempre que servir para esse desiderato, será necessária, bem como as prestações de cunho social (e especialmente tais prestações), sem que isso signifique a assunção de um modelo socialista. Da mesma forma, a consagração da liberdade, incluindo a livre iniciativa e a livre concorrência, serão essenciais para que se implemente aquele grau de desenvolvimento desejado" (TAVARES, André Ramos. Direito Constitucional Econômico. São Paulo: Método, 2003. p. 68). 
Diante do dispositivo, ao se ver a distinção entre "normativo" e "regulador", deve-se ponderar que à regulação é essencial o caráter normativo, mas não um normativo que se assemelhe a "legislativo" ou a "regulamentar". Seria um meio-termo entre o aspecto legislativo e o regulamentar, ou seja, um quase-regulamentar e um quase-legislativo.

Antes de se lançar a análise sobre o conceito de regulação, compete indagar o motivo, o fundamento que ampara o Estado a regular a economia. Ricardo Rivero Ortega responde a essa questão da seguinte forma:

Es una cuestión sobradamente tratada por la teoría económica, siendo bien conocidas las respuestas sobre fallos del mercado: competencia insuficiente, externalidades negativas o carencias de información. Estos problemas, concretados en abusos sobre los consumidores, riesgos para el entorno natural (deterioro del ambiente) y prácticas de aprovechamiento de la ventaja informativa, obligan al Estado y a la Administración a poner límites, pues de outra manera los fraudes y los excesos serían constantes. Aun reconociendo también la existencia de fallos del Estado ${ }^{14-15-16}$, hoy se acepta que la intervención pública em la Economía es imprescindible, como explica el informa del Banco Mundial de junio de 1997 sobre el papel del Estado en un mundo em cambio, y no sólo como aparato de coacción y represión, sino también por su efecto catalisador. ${ }^{17}$

Vê-se, da exposição, que a regulação estatal tem origem na resposta do Estado às falhas de mercado, decorrentes, em grande medida, de com-

14 No década 1970, iniciou-se uma inflexão crítica em relação à regulação econômica realizada pelo Estado. Os teóricos começaram a identificar as falhas de governo. Em 1971, George J. Stigler, da Universidade de Chicago, publicou um artigo com a tese central de que a "regulação é adquirida pela indústria e é desenhada e operada primariamente para o seu benefício". Nesse artigo, é deixada de lado a visão do Estado como um ente benevolente. $O$ Estado é retratado como uma fonte potencial de ameaça aos recursos e a toda atividade econômica na sociedade (STIGLER, George J. The theory of economic regulation. The Bell Journal of Economics and Management Science, v. 2, n. 1, p. 3, Spring, 1971). Nesse período, foi estendida a intuição básica da teoria da captura, por meio da qual o setor regulado influenciaria o ente regulador.

15 As agências seguem também passíveis dos riscos da captura, que podem ser decorrentes do risco de concussão, ou seja, da corrupção dos seus agentes; da captura por contaminação de interesses, quando a agência entroniza os valores e interesses do regulado, como se fossem os interesses gerais da coletividade; pela captura da insuficiência de meios, ou seja, quando o órgão regulador tem esvaziados os seus recursos materiais, logísticos, financeiros e humanos, implicando a falta de interlocução por falta de expertise e falta de autoridade; pela captura por parte do poder político, ou seja, pelos interesses conjunturais do bloco de poder, das vicissitudes eleitorais (cf. MARQUES NETO, Floriano Azevedo. A nova regulação estatal e as agências independentes. In: SUNDFELD, Carlos Ari (Coord.). Op. cit.. p. 89).

16 Nas lições do Professor Ricardo Rivero Ortega: "La teoría de la rent-seeking (búsqueda de rentas) ponde de manifiesto los fallos del Estado y del sector público, contrapunto de los fallos del mercado. Muchas veces se politizan las decisiones económicas públicas (public choice) dando lugar al despilfarro y a las regulaciones ineficientes. [...] La competencia por la busqueda de rentas implica a sujetos públicos y privados, em actividades legales e ilegales (corrupción), dando lugar a 'mercadeos legislativos', captura de los reguladores por los grupos de presión, y a la creciente importância del papel de la Administración y de Ios burócratas como intermediadores de este proceso" (ORTEGA, Ricardo Rivero. Nociones generales sobre derecho administrativo económico. In: CARDOZO, José Eduardo Martins; QUEIROZ, João Eduardo Lopes; SANTOS, Walquíria Batista dos Santos (Coord.). Direito administrativo econômico. São Paulo: Atlas, 2011. p. 31).

17 Idem, p. 22. 
petências insuficientes, insuficiência de bens públicos, externalidades negativas $^{18}$ e carências de informação, ou seja, assimetrias informacionais ${ }^{19}$. Além disso, ela surge como instrumento de retificação das próprias falhas do Estado, entre as quais se destaca o risco da captura.

Perpassados os fundamentos da regulação, compete direcionar o foco à sua delimitação conceitual. $\mathrm{O}$ Estado passou por duas ondas regulatórias. A primeira, de regulação exclusivamente econômica ${ }^{20}$, marcada por uma intervenção estatal destinada a suprir as deficiências e insuficiências do mercado. A segunda, informada pela regulação social, parte da constatação de que o funcionamento perfeito do mercado pode não conduzir à realização de determinados fins de interesse comum. Dessa forma, seria possível a intervenção do Estado para assegurar a distribuição de rendas e assegurar o consumo obrigatório de certos serviços, bem como para a realização de fins de natureza sociopolítica, diante da redução da intervenção estatal direta ${ }^{21}$.

A onda econômica da regulação, que merecerá um estudo mais detido neste artigo, é analisada por duas óticas: a da análise normativa como uma teoria positiva, que se baseia no que deve ser a regulação econômica, a partir de um ponto de vista de eficiência econômica, e a da análise positiva, elaborada pela economia política, que destaca a distância entre os objetivos

18 As externalidades decorrem de ações que geram em contrapartida não apenas custos (ou benefícios) para as partes envolvidas, mas custos (ou benefícios) para terceiros, de forma a se configurarem, respectivamente, externalidades negativas (ou positivas). O surgimento das externalidades decorre da ineficiência da alocação de recursos que não foi devidamente analisada pelos executores das ações. Há, a par dessas duas modalidades de externalidades, uma terceira, nominada de externalidade pecuniária. Ela tem origem em uma ação que gera externalidades positivas e negativas que mutuamente se anulam (cf. ARAÚJO JÚNIOR, Ari Francisco de. Microeconomia. In: TIMM, Luciano Benetti. Direito e economia no Brasil. São Paulo: Atlas, 2012. p. 67-70).

19 A assimetria de informação decorre dos custos necessários à sua obtenção, o que pode resultar no risco moral e na seleção adversa. O risco moral decorre da impossibilidade de se observarem as ações das partes na formulação de um contrato, de maneira que elas não podem ser nele incorporados. É uma ação oculta. A seleção adversa ocorre quando um lado do mercado não pode observar a qualidade ou tipo dos bens no outro lado do mercado. 0 tipo é oculto. 0 exemplo disso é o mercado de seguros de saúde. A insuficiência de bens públicos também é uma falha de mercado e decorre da não rivalidade ínsita ao seu consumo, ou seja, todos dele podem se beneficiar. Além disso, eles são não exclusivos e universalizáveis. A assimetria de informação - que é uma falha de mercado - surge do fato que o regulador não tem todas as informações a respeito dos custos do regulado ou nível de esforço empreendido por ele. Dessa forma, a regulação eficiente, que deveria buscar a eficiência regulatória máxima - first best -, maximizando o equilíbrio entre consumidores e produtores, somente conseguiria atingir a solução second best, tendo em vista as restrições decorrentes da assimetria de informação entre regulador e regulado (CAMPOS, Humberto Alves de. Falhas de mercado e falhas de governo: uma revisão da literatura sobre regulação econômica. Prismas: Dir., Pol. Publ. e Mundial., Brasília, v. 5, n. 2, p. 341-370, jul./dez. 2008, p. 348 e ss.).

20 Nos termos de Posner, "regulação econômica é a expressão que se refere a todos os tipos de impostos, subsídios, bem como os controles legislativo e administrativo explícitos sobre taxas, ingresso no mercado e outras facetas da atividade econômica" (POSNER, Richard A. Theories of economic regulation. N. 41: NBER, 1974. (Working paper, n. 41), p. 1).

21 Cf. JUSTEN FILHO, Marçal. O direito das agências reguladoras independentes. São Paulo: Dialética, 2002. p. 31-38. 
da regulação e a dinâmica própria dos entes regulatórios, condicionada às motivações de diversos grupos de interesse.

Sumariando os conceitos das duas análises da regulação econômica, têm-se as lições de Humberto Alves de Campos:

A análise normativa enfatiza que o mercado apresenta falhas que devem ser corrigidas pelo governo por meio de atividades regulatórias. As principais falhas são imperfeições na concorrência - em geral monopólios ou oligopólios -, externalidades, assimetrias de informação e insuficiente provisão de bens públicos.

A análise positiva - denominada teoria econômica da regulação - incorpora elementos da ciência política para avaliar as limitações da aplicabilidade das soluções normativas. Nesse sentido, a teoria analisa as falhas de governo que dificultam a implementação de políticas que deveriam ser estabelecidas - sob o ângulo normativo - para solucionar falhas de mercado. ${ }^{22}$

Assim, diante da exposição, pode-se antever que a análise normativa leva em conta uma postura estática da regulação e que a análise positiva leva em conta uma postura dinâmica. Para os fins dessa análise, far-se-á uso das duas análises, a primeira para verificar a conformação da regulação e a segunda para propor soluções de redimensionamento institucional.

Lançadas as premissas teóricas, direciona-se o estudo para o conceito de regulação no âmbito do direito pátrio. Nesse passo, Alexandre Santos de Aragão conceitua o termo "regulação" da seguinte forma:

A regulação estatal da economia é o conjunto de medidas legislativas, administrativas e convencionais, abstratas ou concretas, pelas quais o Estado, de maneira restritiva da liberdade privada ou meramente indutiva, determina, controla ou influencia o comportamento dos agentes econômicos, evitando que lesem os interesses sociais definidos no marco da Constituição e orientando-os em direções socialmente desejáveis. ${ }^{23-24}$

\section{Para Diogo Figueiredo Moreira Neto:}

A regulação, até mesmo por suas características enunciadas, é uma função administrativa, que não decorre, assim, do exercício de uma prerrogativa do poder público, mas, muito pelo contrário, decorre da abertura para a lei, de um espaço

22 CAMPOS, Humberto Alves de. Op. cit., p. 365.

23 ARAGÃo, Alexandre Santos de. Agências reguladoras e a evolução do direito administrativo econômico. 2. ed. Rio de Janeiro: Forense, 2009. p. 37.

24 Há três poderes inerentes à regulação: o de editar a regra, o de assegurar sua aplicação e o de reprimir as infrações (GENTOT, Michel. Les Autorites administratives independants. 2 ed. Paris: Montcherestien, 1994. p. 41). 
decisório reservado a uma ponderação politicamente neutra de interesses concorrentes em conflitos setoriais, potenciais ou efetivos. ${ }^{25}$ (itálico do original)

Como se depreende dos conceitos lançados, verifica-se que a regulação estatal se utiliza de uma pluralidade de fontes para controlar e influenciar os agentes econômicos dentro de uma concepção de atendimento aos desígnios da Constituição Econômica.

Todavia, para compreender a regulação nacional, compete delimitar o seu contexto de implantação. Diferente do que ocorreu nos Estados Unidos, onde a regulação foi implementada para coibir abusos (as falhas de mercado), a regulação brasileira teve o objetivo de diminuir a atividade estatal direta (decorrente da prestação de serviços de utilidade pública e da produção de bens pelas empresas estatais).

A regulação, no Brasil, para além da finalidades de diminuição do Estado sobre a atividade econômica, teria como objetivos: que o Estado desempenhasse suas atividades de forma eficiente; fosse efetuado o aumento do acesso à iniciativa privada interessada em prestar serviços públicos por meio dos procedimentos específicos; fosse assegurado o direito de todos os cidadãos aos serviços essenciais, quer seja no espectro das redes de fornecimento do serviço regulado, quer seja pela universalização dos serviços, por meio de tarifas razoáveis aos cidadãos de baixa renda ${ }^{26}$.

É essa a orientação que deve permear a nova compreensão do Estado Regulador, um Estado que, para além da garantia dos direitos do indivíduo, promova o adimplemento de interesses de maior dimensão ${ }^{27}$.

\subsection{A delegação, a desregulação, a reRregulação, a autorregulação e a regulamentação}

A especialização, a complexidade e a variedade de questões regulatórias determinam a necessidade de que parcela significativa da regulação estatal seja delegada ao órgão regulador. Isso se torna possível diante dos instrumentos de mediação e interlocução que viabilizam a produção de

25 MOREIRA NETO, Diogo de Figueiredo. Direito regulatório. Rio de Janeiro: Renovar, 2003. p. 132-133.

26 Cf. FABRI, Andréa Queiroz. A contradição entre a concessão administrativa em monopólio e o direito de acesso aos mercados: desafios para a regulação e para os direitos dos usuários dos serviços públicos. Revista de Direito Público da Economia - RDPE, Belo Horizonte, a. 6, n. 23, p. 41-57, jul./set. 2008, p. 50-51.

27 Vital Moreira distingue três instrumentos de regulação: a estatal, orientada pelo interesse público e pela regulação autoritária; a do mercado (nos moldes da mão invisível de Adam-Smith), orientada pelo interesse pessoal e pela concorrência; e a autorregulação (quando as organizações privadas assumem funções regulatórias), orientada pelo interesse público e privado e pela autodisciplina. (MOREIRA, Vital. Autoregulação profissional e administração pública. Coimbra: Livraria Almedina, 1997. p. 21). 
regras, instrumentos e decisões com maior possibilidade de produção de efeitos ${ }^{28-29}$.

A desregulação designa uma mudança de postura, um rearranjo institucional para permitir que setores considerados essenciais, por critérios eminentemente políticos, sejam regulados com eficiência ${ }^{30-31}$.

\author{
Além da desregulação, surgem as ideias de rerregulação e autorregu- \\ lação.
}

28 MARQUES NETO, Floriano Azevedo. A nova regulação estatal e as agências independentes. In: SUNDFELD, Carlos Ari (Coord.). Op. cit., p. 82.

29 Contudo, deve-se ponderar, como Marcelo Rebelo de Sousa, que a possibilidade de delegação não afasta a reserva legal, sendo imperiosa a técnica da densificação normativa para fixar os contornos da atuação administrativa: "A reserva da lei exige, portanto, que a norma habilitante de actuação administrativa tenha uma determinada densidade - ou seja, um determinado grau de especificação e pormenorização, quer dos pressupostos, quer dos meios, de tal actuação. Se uma norma habilitante de actuação administrativa não possuir o grau necessário de densidade, ela é inconstitucional por violação ao princípio da reserva de lei" (SOUSA, Marcelo Rebelo de; MATOS, André Salgado de. Direito administrativo geral: introdução e princípios fundamentais. 3. ed. reimp. Alfragide: Dom Quixote, t. I, 2010. p. 176-177). Nesse sentido, o grau de densidade normativa varia de acordo: a) com a incidência da atuação administrativa habilitada na esfera social. Ele será maior quando se trate de agressão a direitos, liberdades e garantias e menor quando se trate de administração prestacional ou com incidência tendencialmente neutra; b) a previsibilidade da atuação administrativa, independentemente de previsão legal. Quanto maior a imprevisibilidade, maior o grau de densificação; c) o grau de legitimidade da administração normativamente habilitada. Quanto maior o teor democrático, menor a densificação (idem, p. 176).

30 Fazendo um paralelo entre os sistemas norte-americano e o nacional, Fernando Dias observa que: "Vale ressaltar que aquilo que os norte-americanos, com mais intensidade desde o início da década de 1980 do século passado, passaram a denominar desregulation, querendo significar diminuição da regulação pelo Estado (o que não significa a eliminação da ação reguladora do Estado, mas sua remodelação, v.g., por meio de entidades independentes, nos moldes das nossas agências reguladoras), corresponde mais ao significado atual de regulação no Brasil, em que pese ter gerado entre nós a tradução 'desregulação'" (ALMEIDA, Fernando Dias Menezes de. Teoria da regulação. In: CARDOZO, José Eduardo Martins; QUEIROZ, João Eduardo Lopes; SANTOS, Walquíria Batista dos Santos (Coord.). Op. cit., p. 1016-1017). Nesse sentido, veja-se: DI PIETRO, Maria Sylvia Zanella. Parcerias na Administração Pública. 3. ed. São Paulo: Atlas, 1999. p. 140 e ss.; e JUSTEN FILHO, Marçal. Op. cit., p. 42 e ss.

31 Ao tratar da desregulação no âmbito norte-americano, Gérard Marcou bem sintetiza a tessitura histórica do termo: "La reglamentación limitaba o incluso excluía la competencia, por los derechos exclusivos que ella podia otorgar. Las críticas que sufrió esta política durante los años 60 y 70 llevaron a que fuera cuestionada a partir de la presidencia de Jimmi Carter, quien llevó a cabo una política que tuvo el propósito de suprimir las regulamentaciones que obstaculizaban la libre competencia. [...] Esta política de desregulación, que habíamos traducido en esse entonces correctamente por "desreglamentación", condujo a una revisión fundamental de la reglamentación de numerosos sectores económicos, aquellos todavia llamados "industrias reguladas". Para crear condiciones para la libre competencia se eliminaron las reglamentaciones que apuntaban justamente a redurcila o a excluirla [...] Desde entonces, la reglamentación tiene el propósito de crear las condicionaes para la competencia, y no sustituirla; la agencia, quando existe, viene a ser una agencia sectorial para la competencia. Si hay una influencia estadounidense sobre las experiencias europeas, se da sobretodo teniendo em cuenta esa diferencia: es la desregulation estadounidense la que podemos considerar como una de las fuentes de la regulación em Europa, pero su verdadero alcance no se percibió: lo que estaba en juego era más la creación de condiciones de mercados competitivos que el aligeramiento del peso de la regulación. La outra lección de la evolución reciente de la regulación en los Estados Unidos muchas veces se omite: la regulación está sometida al control del Congresso, pero se asegura la independencia de la "función adjudicativa", que corresponde a decisiones individuales" (MARCOU, Gérard. La regulación y los servicios públicos. Las enseñanzas del derecho comparado. In: MARCOU, Gerard; MODERNE, Frank (Directores). Derecho de la regulación, los servicios públicos y la integración regional. t. I. Bogotá: Editorial Universidad del Rosario, 2009. p. 26). 
A rerregulação, nas palavras de Justen Filho,

significa a defesa da substituição das regras inadequadas por outras, mais compatíveis com a nova realidade social e tecnológica, menos onerosas para a sociedade em seu conjunto e produzidas segundo parâmetros de participação da sociedade civil. ${ }^{32}$

A autorregulação, por sua vez, seria a regulação privada, a regulação de determinado setor da sociedade por entes privados, voltada à ação de outros entes privados ${ }^{33}$.

Em contraposição à regulação, tem-se no sistema jurídico nacional a regulamentação. Ela envolve o exercício do poder normativo de caráter geral e abstrato inerente à Administração, de competência privativa própria do Presidente da República.

Além do regulamento de execução, fundado na regulamentação, há no Brasil regulamentos que não têm como objeto a execução de lei. São regulamentos que sequer dependem da existência de lei sobre a matéria, podendo-se dizer regulamentos independentes ${ }^{34-35}$. São casos de regulamentos sobre organização da própria Administração (exemplo: CF, art. 84, VI, com a redação dada pela Emenda no 32/2001); ou sobre matérias que dizem respeito a direitos e obrigações dos indivíduos, excepcionalmente indicadas pela Constituição (exemplo: CF, art. 84, IX, c/c os arts. 136-139; art. 84, X, c/c os arts. 34-36).

Pois bem. Esses são os conceitos próximos, derivados e contrapostos ao de regulação no âmbito do cenário nacional.

\subsection{PRINCIPAL INSTRUMENTO dA REGULAÇÃo No DIREITO NaCIONAL}

As agências reguladoras se constituem como autarquias especiais, pessoas jurídicas de direito público interno, que fazem parte da Administração indireta. Elas são criadas por lei e possuem autonomia administrativa e financeira. Dentro desse escopo, possuem o poder de expedir normas que vinculam todo o setor regulado e não somente as regras de ordem inter-

32 JUSTEN FILHO, Marçal. Op. cit., p. 45.

33 Cf. ALMEIDA, Fernando Dias Menezes de. Teoria da regulação. In: CARDOZO, José Eduardo Martins; QUEIROZ, João Eduardo Lopes; SANTOS, Walquíria Batista dos Santos (Coord.). Op. cit., p. 1017.

34 Nos dizeres de Pontes de Miranda: "O poder regulamentar não deriva de delegação legislativa" (PONTES DE MIRANDA. Comentários à Constituição de 1967 com a Emenda no 1 de 1969. 2. ed. São Paulo: Revista dos Tribunais, t. III, 1970. p. 312).

35 Existem vozes na doutrina que preferem o uso da expressão "regulamentos autônomos" no Direito Nacional. Entre todas, veja DI PIETRO, Maria Sylvia Zenella. Op. cit., p. 91 e ss. 
na. Assim, as resoluções de conselhos e agências, no Brasil, servem para complementar os aspectos em que a lei que as instituiu se mostra falha, ou melhor, que o próprio legislador, por carência de conhecimento técnico especializado, delegou àqueles entes. Assim, elas possuem poder de sanção ${ }^{36}$.

Elas possuem outras características legais, a seguir listadas: ampla publicidade de normas, procedimentos e ações; celeridade processual e simplificação das relações entre consumidores e investidores; participação de todas as partes interessadas no processo de elaboração de normas em audiências públicas; limitação da intervenção estatal na prestação de serviços públicos aos níveis indispensáveis à sua execução ${ }^{37}$.

Sobre o acento constitucional das agências reguladoras, Tércio Sampaio Ferraz Júnior se posiciona da seguinte forma:

A competência das agências reguladoras encontra embasamento no art. 174 da $\mathrm{CF}$, consoante o qual o Estado é "agente normativo e regulador da atividade econômica" e exerce "as funções de fiscalização, incentivo e planejamento, sendo este determinante para o setor público e indicativo para o setor privado". Mas ela vem informada pelo dever de racionalidade, que, imposto ao Legislador, combina a atividade (agente) normativa com a reguladora. Pela primeira, cabe ao Estado, mediante lei, fixar diretrizes para a economia. Pela segunda, realizar o que os economistas chamam de intervenção conforme, isto é, orientar e influenciar os agentes econômicos por meio de políticas globais que equilibrem níveis de demanda, condições de repartição, eficiência na alocação e distribuição de recursos, sem lhes eliminar a livre determinação.

Em suma, o poder regulador das agências encontra limites no princípio da eficiência, o que faz com o que o seu controle seja exercido sobre a razoabilidade de seu conteúdo. ${ }^{38}$

Todas essas linhas impõem a intenção legislativa e administrativa de se criarem agências com procedimentos mais democráticos, quer seja por meio do acesso nos mercados, quer seja por maior participação na tomada de decisões, dentro dos parâmetros constitucionais.

Nesse sentido, Alexandre Santos de Aragão assesta ser o estudo das agências reguladoras uma importante oportunidade para a renovação do

36 Cf. FABRI, Andréa Queiroz. A contradição entre a concessão administrativa em monopólio e o direito de acesso aos mercados: desafios para a regulação e para os direitos dos usuários dos serviços públicos. Revista de Direito Público da Economia - RDPE, Belo Horizonte, a. 6, n. 23, p. 41-57, jul./set. 2008, p. 49.

37 Cf. NUNES, Edson. Agências regulatórias: gênese, contexto, perspectivas e controle. Revista de Direito Público da Economia - RDPE, Belo Horizonte, n. 2, p. 163-220, abr./jun. 2003, p. 179.

38 FERRAZ JUNIOR, Tércio Sampaio. Como regular agências reguladoras? Revista Brasileira de Direito Público, Belo Horizonte, a. 6, n. 22, p. 22, jul./set. 2008. 
direito administrativo. Para ele, as agências reguladoras são um modelo organizativo totalmente novo que representa importante oportunidade de renovação do direito administrativo como um todo, principalmente pelo fato de estar diretamente relacionada ao direito administrativo econômico ${ }^{39}$.

\section{UM CONTRIBUTO INSTITUCIONAL À REGULAÇÃO}

\subsection{A PERSPECTIVA INSTITUCIONAL}

Sumariado o quadro jurídico econômico da regulação, deve-se volver o olhar para o contributo da perspectiva neoinstitucional em relação à regulação nacional.

Como relatado no primeiro capítulo, a regulação tem como seu fundamento a correção das falhas do mercado, assegurando-lhe o equilíbrio, ou seja, a correção das competições imperfeitas. Para além disso, dentro da ordem constitucional brasileira, ela deve introduzir objetivos que não seriam alcançados pela iniciativa privada. Nesse sentido, ela busca redimensionar as externalidades, as assimetrias de informações e as insuficientes provisões de bens públicos ${ }^{40}$, além de reduzir os riscos de captura.

Nesse passo, deve-se, preliminarmente, aclarar o que é a perspectiva neoinstitucional. A virada institucional leva em conta o fato de serem insuficientes as técnicas de interpretação do direito que não considerem os efeitos sistêmicos e a capacidade institucional do órgão responsável pela decisão.

A nova economia institucional busca oferecer uma renovada concepção das firmas no sistema capitalista, enfatizando a interação com o arranjo institucional, dada a notória incapacidade da teoria neoclássica em dar atenção adequada ao papel preponderante das instituições no funcionamento dos mercados ${ }^{41}$.

Nesse sentido, no entendimento da nova economia institucional, é impossível obter o funcionamento perfeito dos mercados diante da impossibilidade de se criarem modelos probabilísticos para tratar das incertezas em relação ao futuro. As incertezas são geradas por uma série de fatores, quais sejam: a) racionalidade limitada dos agentes, que os impede de tomar

39 Cf. ARAGÃO, Alexandre Santos de. Agências reguladoras: algumas perplexidades e desmistificações. Interesse Público, Rio de Janeiro: Fórum, a. 10, n. 51, p. 73, set./out. 2008.

40 Cf. CAMPOS, Humberto Alves de. Op. cit., p. 343 e ss.

41 SILVA FILHO, Edison Benedito da. A teoria da firma e a abordagem dos custos de transação: elementos para uma crítica institucionalista. Pesquisa \& Debate, São Paulo, v. 17, n. 2 (30), p. 259-277, 2006, p. 262. 
continuamente decisões maximizadoras de bem-estar; b) o comportamento oportunístico dos agentes, que os motiva a agir de modo a obter benefícios de outros agentes com os quais transacionam; c) a assimetria de informações, que implica um acesso desigual dos agentes às informações pertinentes à troca por eles realizada, impedindo que ela se dê da maneira mais vantajosa do ponto de vista da sociedade; d) a impossibilidade de contratos completos, capazes de prever todos os eventos possíveis em um ambiente de incerteza ${ }^{42}$.

Muito se falou sobre os fundamentos da nova economia institucional. Nesse momento, importa delimitar o seu aspecto principal, a conformação do que sejam as instituições. Segundo Douglass North, as instituições:

São as constrições humanamente concebidas que estruturam a interação humana. Elas são feitas de restrições formais (regras, leis, constituições), de restrições informais (normas de comportamento, convenções e códigos de conduta autoimpostos) e de suas respectivas características impositivas. Juntas, elas definem a estrutura de incentivos das sociedades e, especificamente, das economias. As instituições e a tecnologia empregada determinam os custos de transação e de transformação que se somam aos custos de produção. [...] O resultado neoclássico dos mercados eficientes somente é obtido quando não existem custos para se transacionar. [...] Quando se tem custo para transacionar, as instituições são importantes..$^{43-44}$

Para a nova economia institucional, é a interação entre as instituições e as organizações que modela a evolução institucional de uma economia. Se as instituições são as regras do jogo, as organizações e seus empresários são os jogadores. As organizações são constituídas por grupos de indivíduos unidos para atingir certos objetivos ${ }^{45}$.

42 Idem, p. 263.

43 NORTH, Douglass C. Desempenho Econômico através do tempo. Tradução de Antonio José Maristrello Porto. Revista de Direito Administrativo, Rio de Janeiro: FGV, v. 255, p. 13-30, set./dez. 2010, p. 16.

44 A importância das instituições, em especial de seu desenho institucional, é bem delineada por Marcos Lisboa: "A solidez e o impacto de boas instituições são determinados por seu desenho específico e pela consistência de longo prazo dos incentivos gerados pelas regras do jogo. A maioria dos mercados funciona adequadamente desde que os contratos sejam respeitados e os acordos, cumpridos. Em alguns casos, porém, é necessário maior regulação por parte do setor público, ou regras institucionais específicas, para que se garanta maior bem-estar social. São principalmente as especificidades do desenho institucional, e não a maior ou menor participação do Estado, que determinam a distribuição e o provimento dos serviços. [...] o cuidado com a construção das instituições - ou seu descuido gerado por pressões do momento - não gera resultados significativos no curto prazo, mas é fundamental no longo prazo. Não se deve medir um governo ou uma gestão pelos resultados obtidos durante sua ocorrência, e sim por seus impactos no longo prazo, pelos resultados que são verificados nos anos que se seguem ao seu término. Instituição importam, e os impactos decorrentes da forma como são geridas ou alteradas se manifestam progressivamente, porém são inexoráveis" (LISBOA, Marcos. Instituições e crescimento econômico. In: BACHA, E.; BOLLE, M. (Org.). Novos dilemas da política econômica: ensaios em homenagem a Dionísio Dias Carneiro. Rio de Janeiro: Casa das Garças/LTC, 2011. p. 232-233).

45 NORTH, Douglass C. Op. cit., p. 18. 
Mas, para se compreender a dinâmica das relações entre as instituições e as organizações, importante se torna a compreensão de um dos conceitos mais importantes da nova economia institucional, qual seja, dos custos de transação.

O conceito de custos de transação foi apresentado por Ronald Coase em 1937, no artigo "The Nature of the Firm" ${ }^{46}$. Coase se referiu aos custos de transação como os custos para a utilização dos mecanismos de preços. Por meio desta concepção, percebe-se que qualquer interação econômica implicará o dispêndio de recursos para a sua operacionalização. Kenneth Arrow definiu os custos de transação como os custos para conduzir o sistema econômico ${ }^{47}$.

Nos dizeres de Egon Bockmann Moreira, os custos de transação dizem respeito ao conjunto do trabalho, tempo e dinheiro que envolvem um negócio. Eles não representam um valor intrínseco ao negócio. São situações relacionadas ao levantamento de informações contratuais objetivas, ao exame sobre as pessoas dos respectivos contratantes, à elaboração dos contratos, à proteção ao meio ambiente e ao controle da execução contratual, etc. ${ }^{48}$.

Os custos de transação incorrem diante da presença de três suposições, são elas: a racionalidade limitada; o oportunismo, que consiste na maneira mais forte de se buscar o interesse próprio, que pode passar por práticas desonestas, incluindo mentir, trapacear, roubar, esconder ou distorcer informações; e a de que o capital nem sempre pode ser transferido de uma atividade para outra a custo zero, sendo frequente que um determinado ativo muito produtivo em uma atividade (transação) seja menos produtivo em outra ${ }^{49}$.

Como relatado, os custos de transação dizem respeito aos fatores que não se encontram intrinsecamente no valor do negócio e são representados pelos custos de procura e obtenção de informações e pelos custos de negociação e de execução do contrato. A origem deles decorre da racionalidade limitada dos pactuantes, do oportunismo e da compreensão de que nenhum bem será transferido de uma atividade para outra a custo zero.

46 COASE, Ronald H. The nature of the firm. New Series, v. 4, n. 16, p. 386-405, nov. 1937, passim.

47 ARROW, Kenneth. The organization of economic activity: issues pertinent to the choice of market versus non-market allocation. The analysis and evaluation of public expenditures. The PBB-System, Joint Economic Committee, $91^{\text {st }}$ Congress, $1^{\text {st }}$ session, v. 1. Government Printing Office: Washington, D.C., 1969, passim.

48 MOREIRA, Egon Bockmann; GUIMARÃES, Fernando Vernalha. Op. cit., p. 97.

49 WILLIAMSON, Oliver E. Why Law, Economics and Organization? December 2000. UC Berkeley Public Law Research, Paper n. 37. Disponível em: <http://ssrn.com/abstract=255624>. Acesso em: 8 jul. 2012, p. 7. 
A importância dos custos de transação e das instituições pode ser extraída do teorema de Coase. Por meio dele, em situações em que os custos de transação são baixos, a barganha livre e cooperativa entre os agentes tende a um resultado de maximização de ganhos, ou seja, a eficiência. Entretanto, quando os custos de transação se apresentam significativos, as livres forças do mercado, neste caso, não podem garantir a eficiência do sistema. Nesse sentido, caberia às instituições legais a responsabilidade pela maximização do bem-estar social. São as instituições que, na verdade, governam o desempenho da economia. Assim, as instituições agem de duas formas sobre o resultado econômico final: uma ex ante, determinando os custos de transação da economia; outra ex post, de maneira a corrigir os resultados ineficientes ${ }^{50-51}$.

Dentro do contexto regulatório, a execução das políticas governamentais por meio da regulação, ou seja, por seus instrumentos, as agências reguladoras, moldaria significativamente o desempenho econômico, porque elas definem e aplicam as regras da economia. Portanto, uma parte essencial da política do desenvolvimento é a criação de instituições que criem e façam valer os direitos de propriedade eficientes, no caso, a condução das atividades econômicas de forma eficiente ${ }^{52}$.

Assim, ao efetuar uma análise institucional, deve-se levar em conta a idoneidade de cada um dos Poderes, em virtude de sua estrutura orgânica, legitimidade democrática, meios e procedimentos de atuação, preparação técnica, etc. ${ }^{53}$.

\subsection{Propostas de ReVISÃo InStituCIONAL da ReGULaÇão}

Entende-se ser questão preliminar ao lance de propostas de revisão institucional da regulação a identificação das falhas que se encontram no sistema regulatório pátrio.

Nesse intento, como declinado em todo o transcurso deste trabalho, verificou-se que da parte das falhas do mercado, ou seja, das assimetrias informacionais, da insuficiente provisão de bens públicos e das externali-

50 Cf. COASE, Ronald. The problem of social cost. Journal of Law and Economics, 1960, passim.

51 Cf. RAVINA, Carlos Morales de Setién; POSNER, Richard A.; LANDES, William M.; KELMAN, Mark G. Análisis Económico del derecho. Bogotá: Siglo del Hombre Editores; Universidad de los Andes; Pontificia Universidad Javeriana-Instituto Pensar, 2011. p. 50-57.

52 NORTH, Douglass C. Op. cit., p. 27-28.

53 KRELL, Andreas Joachin. Discricionariedade administrativa e proteção ambiental: o controle dos conceitos jurídicos indeterminados e as competências dos órgãos ambientais. Um estudo comparativo. Porto Alegre: Livraria do Advogado, 2004. p. 45 e ss. 
dade e da parte das falhas do Estado, diante da possibilidade de captura pelos grupos de pressão, a regulação necessita de propostas de rearranjo institucional necessárias a dar solução para alguns problemas encontrados.

Em compasso com os problemas elencados, pede-se vênia para listar e adaptar ao contexto nacional os problemas encontrados por Cass Sunstein em relação à regulação. Nesse intento, ele destaca as falhas de coordenação do executivo, a falta de deliberação política e de responsabilidade, a falta de controle políticos (accountability) e a influência de grupos políticos atuantes em favor dos próprios interesses. Em decorrência desses argumentos, levanta os seguintes problemas: a) decorrentes da modelagem concebida na lei que institui o regime regulatório: a.i) a identificação da lei com interesses de grupos privados bem organizados (stakholders) ${ }^{54}$; a.ii) leis baseadas em diagnósticos equivocados, análise deficiente de políticas e má-informação; a.iii) insensibilidade das leis às dificuldades práticas; a.iv) falhas do Legislativo no entendimento de complexos e sistêmicos efeitos das intervenções regulatórias; a.v) falhas de coordenação decorrentes da multiplicação de leis que regulam o mesmo objeto, por vezes, de forma incoerente; a.vi) falhas legais em razão da mudança de circunstâncias e da obsolescência das disposições existentes; a.vii) falhas legais decorrentes da substituição de razões tecnocráticas pelas políticas; b) decorrentes dos erros de implementação dos comandos legais: b.i) insucesso nas estratégias de implementação da regulação; b.ii) pressão de grupos de interesse sobre as agências; b.iii) inadequada informação e equívocos de análise técnica por parte dos funcionários das agências; b.iv) insuficiente consciência dos membros das agências em relação aos efeitos sistêmicos da regulação; b.v) falhas de coordenação na atuação das agências; b.vi) obsolescência de instrumentos e estratégias regulatórias; b.vii) inadequada execução da lei, ou inexecução em virtude da captura por grupos de interesse (stakholders), em decorrência da preservação de interesses da burocracia e por lentidão, torpor ou omissão administrativa; b.viii) controles excessivos ou insuficientes, distorcendo os legítimos fins da regulação legal; b.ix) desvio nos objetivos de leis de regulação e de redistribuição, gerando efeitos oblíquos (beneficiando não exatamente os destinatários da lei) ou perversos (prejudicando, direta ou indiretamente, os próprios destinatários da lei ${ }^{55}$; b.x) processos de decisão não democráticos, de pouca ou nenhuma transparência.

54 Nos Estados Unidos, a prática de lobby é institucionalizada, ao contrário da pouca institucionalização no Brasil decorrente das associações, sindicatos e representações de classe.

55 Sustein também faz uso da expressão "paradoxos regulatórios", que são resultados opostos aos pretendidos pela regulação (SUNSTEIN, Cass. Paradoxes of the regulatory state. The University of Chicago Law Review, v. 57, n. 2, Administering the Administrative State, p. 407-441, 1990). 
Feitos os devidos temperamentos, vislumbra-se que o rol apresentado por Sustein se adapta à realidade regulatória brasileira, devendo-se destacar que a nossa forma de regulação é bem mais abrangente do que a dos norte-americanos e que a noção de serviço público no Brasil abrange setores mais largos da vida econômica.

Desta forma, listados os problemas inerentes à regulação, apresenta-se roteiro para a conformação institucionalmente adequada da intervenção do Estado na economia em face da Constituição Econômica brasileira ${ }^{56}$ : a) dentro de uma perspectiva material, a regulação nacional deve: a.1) na hipótese de aplicação de uma regra, dar reverência a decisões com alto teor de densidade normativa; a.2) no caso de conceitos jurídicos indeterminados, decidir de maneira mais rigorosa nas zonas de certeza negativa e positiva, mediante a demonstração de sua existência; nas zonas de incerteza, aparelhar-se com padrões de densificação normativa, entre os quais os efeitos do princípio da eficiência; a.3) nas zonas de penumbra, de conceitos jurídicos indeterminados, ou na aplicação dos princípios da ordem econômica, deve dar primazia à proporcionalidade das medidas, à análise jurídico-econômica e ao diálogo institucional; a.4) buscar uma racionalidade administrativa comprometida com a eficiência e com a eficácia, isto é, com a concretização dos objetivos fundamentais da República, entre os quais a promoção do bem de todos, conforme o art. $3^{\circ}$ da Constituição Federal. Uma racionalidade que se encontre amparada nas consequências, no caráter empírico das decisões ${ }^{57}$; a.5) ter uma maior preocupação com a motivação, não meramente formal de seus atos ${ }^{58}$, de modo a que o órgão regulador exponha seus fundamentos jurídicos, econômicos e sistêmicos; a.6) entronizar os princípios constitucionais da prevenção e da precaução nas relações administrativas brasileiras, de modo a adotar de maneira cautelar as medidas necessárias. Isto redunda na adoção de medidas proativas de concretização dos direitos fundamentais ${ }^{59}$; a.7) diante da existência de várias soluções na fixação dos parâmetros regulatórios, buscar a medida menos restritiva; a.8) efetuar a análise dos custos e benefícios, aferindo se os efeitos sistêmicos da medida: i) causam resultados contrários às finalidades

56 Cf. CYRINO, André Rodrigues. Direito constitucional regulatório: elementos para uma interpretação institucionalmente adequada da Constituição econômica brasileira. Rio de Janeiro: Renovar, 2010. p. 301-302 e 307-310.

57 Cf. FREITAS, Juarez. Direito fundamental à boa Administração Pública e a constitucionalização das relações administrativas brasileiras. Interesse Público, Belo Horizonte, a. 12, n. 60, p. 13-24, mar./abr. 2010, p. 15-23.

58 Cf. MARQUES NETO, Floriano Azevedo. A nova regulação estatal e as agências independentes. In: SUNDFELD, Carlos Ari (Coord.). Op. cit., p. 79.

59 Cf. FREITAS, Juarez. Op. cit., p. 15-23. 
pretendidas; ii) apresentam efeitos colaterais que não compensem as eventuais vantagens; ou iii) se apresentam como dirigidos para beneficiar um grupo específico ${ }^{60}$. Assim, dentro do sopesamento do custo-benefício, devem ser analisadas: i) a verificação sobre a violação dos direitos fundamentais ligados às liberdades básicas, em especial sobre a violação ao mínimo existencial, que deverão preponderar, quando for necessário, diante da análise fria do custo-benefício; ii) a consideração do risco de erro administrativo na previsão dos efeitos futuros e sistêmicos da medida; iii) a consideração quanto aos custos para a estabilidade do mercado diante da mudança das regras do jogo; iv) a consideração do nível de tecnicidade da matéria; v) a capacidade real (empírica) de o ente regulador tomar decisões interventivas; a.9) afastar as imunidades dos agentes políticos rumo à sindicabilidade ampla das condutas omissivas e comissivas ${ }^{61}$; b) por outro lado, dentro de um viés procedimental, a regulação deve se pautar: b.1) pelo exercício de uma autoridade governamental negocial em permanente construção, em substituição à autoridade unilateral. Esta autoridade deve ser orientada pelo respeito às regras do jogo, pela interlocução com os diversos atores e pela detenção do conhecimento técnico necessário ${ }^{62} ;$ b.2) pela racionalidade do procedimento regulatório, que deverá ser processualizado, com subordinação a regras, ritos e procedimentos claros e preestabelecidos ${ }^{63}$. Dessa forma, deve exercer a atuação administrativa com controle de racionalidade das decisões dadas, de forma a que se compreenda o processo decisório como rigorosamente vinculado aos princípios e direitos fundamentais, decisões estas que só devem ser admitidas quando dotadas de repercussão universalizável em termos sociais, evitando-se considerações estritamente econômicas ou eleitoreiras ${ }^{64}$. Destarte, a regulação deve reafirmar e legitimar procedimentalmente a sua independência diante das demais funções

60 Na França, existe um controle de gestão que compatibiliza a posteriori, ex post, os objetivos traçados com os resultados alcançados: "Le contôle de gestion qui est, on l'a vu, un des éléments de la rationalisation des Choix, n'a plus rien à voir avec les contrôles de type classique: integer à la gestion qu'il encadre de manière permanente, il se présente comme un instrument de mesure des écarts entre les résultats présente come un instrument de mesure des écarts entre les résultats atteints et les résultats attendus, dont l'objet n'est plus la sanction, mais la réorientation de l'action. Tant Dans sa finalité que dans ses modalités, ce contrôle diffère donc profondément Du controle de régularité tradionnel: c'est à la fois un contrôle d'efficacité, par la confrontation des objectifs visés et des résultats obtenus, un contrôle d'efficience, par la confrontation des moyens utilisés et des résultats atteints, et un côntrole de pertinente, par la confrontation des moyens et des objectifs" (CHEVALLIER, Jacques. Science administrative. 2 édition refondue. Paris: PUF, 1994. p. 514).

61 Cf. FREITAS, Juarez. Op. cit., p. 15-23.

62 Cf. MARQUES NETO, Floriano Azevedo. A nova regulação estatal e as agências independentes. In: SUNDFELD, Carlos Ari (Coord.). Op. cit., p. 91-92.

63 Idem, p. 79.

64 Cf. FREITAS, Juarez. Op. cit., p. 15-23. 
estatais $^{65-66}$. Nesse intento, a regulação deve ser reconfigurada para operar como atividade do Estado, não propriamente de governo, competindo o necessário estudo sobre as omissões da não regulação ou da regulação inoperante $^{67}$; b.3) por uma maior capacidade de arbitramento democrático de interesses, o que implica uma maior especialização e monitoramento das atividades reguladas ${ }^{68}$. A gestão deve ser direcionada para a correção acordada, com ênfase na solução administrativa de conflitos, aperfeiçoando-se o uso de termos de ajustamento de conduta, mediação e conciliação no âmbito administrativo. Ela deve ser imparcial e equitativa, vedando-se discriminações negativas e determinando compensações positivas. Desse modo, os apriorismos excludentes, aqueles que delimitam a questão dentro de apenas um princípio constitucional, devem ser obstados. Enfim, deve harmonizar as demandas existenciais e os textos normativos ${ }^{69}$; b.4) pela necessidade do franqueamento de diálogo institucional quando surgido conflito de competências regulatórias; b.5) pelo desenvolvimento de uma radical transparência, traduzida na radicalização do princípio da publicidade e na introdução de efetivos mecanismos de controle pelos sujeitos e interessados no exercício desta atividade ${ }^{70}$; b.6) por uma compreensão de maximização diante dos direitos fundamentais, dentro de um processo de legitimação contínua; b.7) pela observância do tempo útil para a promoção do direito fundamental à boa administração, ou seja, deve atender a tempo e modo o bem de todos ${ }^{71}$.

Em sequência, e no que interessa a esta análise, deve-se pontuar que a independência do regulador é medida essencial para que se evitem as influências dos grupos de interesse (stakholders). O ente regulador deve ser independente diante da relação tripartida que se estabelece em serviços ou atividade de relevância coletiva, que é informada pelo produtor da utilidade pública, pelo seu consumidor e pelo Poder Público (titular último

65 As agências reguladoras, dentro do aspecto independência, devem servir de instrumento às políticas governamentais, não às políticas de um governo (MARQUES NETO, Floriano Azevedo. A nova regulação estatal e as agências independentes. In: SUNDFELD, Carlos Ari (Coord.). Op. cit., p. 87).

66 A expedição de regulamento deve apresentar fundamentação pública de fato e de direito, contemporânea à sua edição. Ainda que geral e abstrato, o regulamento é ato administrativo - e como tal deve ser emanado (Cuéllar, Leila. As agências reguladoras e seu poder normativo. São Paulo: Dialética, 2001. p. 126).

67 Cf. FREITAS, Juarez. Op. cit., p. 15-23.

68 Cf. MARQUES NETO, Floriano Azevedo. A nova regulação estatal e as agências independentes. In: SUNDFELD, Carlos Ari (Coord.). Op. cit., p. 90-92.

69 Cf. FREITAS, Juarez. Op. cit., p. 15-23.

70 Cf. MARQUES NETO, Floriano Azevedo. A nova regulação estatal e as agências independentes. In: SUNDFELD, Carlos Ari (Coord.). Op. cit., p. 79.

71 Cf. FREITAS, Juarez. Op. cit., p. 15-23. 
ou dominus da rede necessária a essa produção ou do monopólio de sua exploração) $)^{72-73}$.

A regulação deve ponderar estas três relações de modo a se evitar o maior peso para um dos três polos. Assim, deve ser obstado o populismo regulatório, deve ser ponderada a proteção dos consumidores potenciais do serviço, ou seja, daquele indivíduo que não pode usufruir do serviço, deve se dar interpretação adequada ao interesse dos usuários mais aquinhoados. Deve-se conter a exorbitância da tutela dos interesses dos usuários, de maneira a que o agente regulador não ceda a pressões indenizatórias que, via de regra, serão resolvidas pelo equilíbrio econômico financeiro dos contratos, acarretando em contrapartida o aumento dos gastos públicos ${ }^{74}$.

Como se viu, a questão da regulação está intrinsecamente relacionada à fixação, à alocação de direitos. Nesse sentido, deve-se ter em mente que a alocação deve ser direcionada àqueles atores sociais que possuam melhores condições de gerenciá-los, de forma a maximizar o valor total do projeto (total project value) ou, melhor dizendo, o valor total dos benefícios à sociedade, considerando a capacidade de cada parte para influenciar o correspondente fator de risco ${ }^{75}$, influenciar a sensibilidade do valor total do projeto em relação ao risco - antecipando ou respondendo ao fator de

72 Cf. MARQUES NETO, Floriano Azevedo. A nova regulação estatal e as agências independentes. In: SUNDFELD, Carlos Ari (Coord.). Op. cit., p. 85.

73 'A função do regulador não é tanto a de se 'se impor' aos regulados, mas de convencer, persuadir, levar as partes a uma solução convencional, na medida do possível. [...] Em muitas das questões que se colocam ao regulador não existe apenas uma única solução 'justa', devendo quase sempre articular uma composição entre interesses contrapostos, uma transição, uma arbitragem. 0 desejável é que a decisão seja, em princípio, aceita pelas partes, o que será facilitado quando a autoridade reguladora, com o passar do tempo, adquira a maturidade e experiência necessárias para cumprir a sua missão, isto é, quando ganhe o respeito dos operadores do sistema e, além da competência legal, goze da auctoritas moral sobre os mesmos." (ORTIZ, Gaspar Ariño. Princípios de derecho público económico. Granada: Comares e Fundación de Estudios de Regulación, 1999. p. 598-599. Tradução livre)

74 Cf. MARQUES NETO, Floriano Azevedo. A nova regulação estatal e as agências independentes. In: SUNDFELD, Carlos Ari (Coord.). Op. cit., p. 86-87.

75 Interessante o posicionamento de Carlos Ari Sundfeld sobre a postura da população diante dos riscos inerentes da atividade econômica: "Só que as pessoas não querem mais correr esse risco. Elas querem controle prévio. E para isso é preciso um órgão administrativo que controle tudo: que previamente examine projetos, planos; que edite os atos administrativos autorizando construir, implantar, fazer, destruir; que fiscalize a execução das atividades, aplicando sanções e cassando licenças - e assim por diante. [...] Mas as pessoas querem mais: que os conflitos individuais nascidos da aplicação de todos estes planos sejam tratados por entidades imparciais - o que sempre se exigiu dos juízes, a imparcialidade. Mas isso não lhes basta. Os conflitos entre uma indústria poluidora, uma outra indústria que usa a água poluída lançada no rio e os vizinhos que também a consumem, quer-se que eles sejam julgados por quem entenda do assunto. Não alguém que entenda de Direito apenas (isto é, das técnicas de produção e hermenêutica normativa), mas que entenda do problema específico: quem saiba das dificuldades para compor harmonicamente o conflito, consiga dar solução mais harmoniosa por equidade, baseando-se em critérios técnicos, [sic] etc." (SUNDFELD, Carlos Ari. Introdução às agências reguladoras. In: SUNDFELD, Carlos Ari (Coord.). Op. cit., p. 30). 
risco - e absorver o risco, isto para aquele que poderá absorvê-lo ao menor custo $^{76}$.

Focando a questão dentro das teorias econômicas neoinstitucionalistas, pode-se afirmar, então, que o desenvolvimento será alcançado quando a evolução das instituições permitir reduzir o grau de risco/incerteza e diminuir os custos de transação ${ }^{77-78}$.

É nesse passo que ganha importância a função reguladora, com sua relevante atividade de harmonização de subsistemas, de forma a direcionar os setores da convivência social e econômica na busca do máximo de eficiência na solução de seus problemas, ponderando para cada hipótese o uso da flexibilidade negocial privada com o rigor da coercitividade estatal ${ }^{79}$.

Assim, propõe-se que o Estado deve avançar paulatinamente para uma Administração que siga de acordo com o princípio da correção de erros (trial and error), ou seja,

no esforço de controlar as consequências de suas ações a fim de as corrigir a tempo. Portanto, avançará apenas passo a passo e sempre acompanhará cuidadosamente os resultados perspectivados com os realmente alcançados, estando continuamente atento aos efeitos secundários indesejáveis. ${ }^{80}$

Nesse sentido, os autores europeus propugnam por uma neorregulação ou regulação por competência, em superação da regulação econômica. A regulação estatal visaria principalmente ao estabelecimento dos quadros para que o mercado se desenvolvesse livremente e regulasse naturalmente suas atividades ${ }^{81}$, respeitando-se, no contexto nacional, a ordem constitucional econômica.

Destarte, o Estado deveria compreender a incompletude do sistema regulatório, de maneira a executar um planejamento estatal que acompanhe diuturnamente os efeitos de suas ações e anteveja os seus efeitos futuros.

Nesse sentido, propõe-se como solução para a regulação brasileira a eficiência adaptativa. Ela se apresenta como a chave para o crescimento de longo prazo. Ela ocorre em sistemas político/econômicos bem-sucedidos

76 Cf. NÓBREGA, Marcos. Op. cit., p. 129.

77 Idem, p. 42.

78 Cf. VIANNA, Salvador Teixeira Werneck. Op. cit., p. 38.

79 MOREIRA NETO, Diogo de Figueiredo. Op. cit., p. 107.

80 Zippelius, Reinhold. Teoria geral do Estado. Tradução de Karin Praefke-Aires Coutinho, Coordenação de J. J. Gomes Canotilho. 3. ed. Lisboa: Fundação Calouste Gulbenkian, 1997. p. 469-470.

81 ORTIZ, Gaspar Ariño. Op. cit., p. 549-603. 
por meio do desenvolvimento de estruturas institucionais flexíveis que podem sobreviver a choques e mudanças que fazem parte da evolução de sucesso. Contudo, como preconiza Posner, esse sistemas são um produto de longa gestação, eles não são gerados em curto prazo ${ }^{82}$.

Assim, a regulação deve ser vista como uma atividade em constante evolução, retroalimentada pelo feedback de suas decisões. Ela deve compreender o contexto fático e histórico em que se encontra para se moldar ao seu fim último, promover o desenvolvimento nacional, sem que isso se configure em um excesso de regulação, mas em uma regulação ponderada, essencial, que coteje a dualidade valor social versus manutenção das atividades econômicas, que são, em última medida, as verdadeiras fomentadoras de recursos para subsidiar as prestações civilizatórias que o Estado deve cumprir.

Então, o direito público tem a complexa missão de regular, de modo equilibrado, as relações entre o Estado - que exerce a autoridade pública e o consequente poder de mando - e os indivíduos - que devem se sujeitar a ele, sem olvidar que eles são os donos do poder e os titulares de direitos próprios $^{83}$.

\section{CONSIDERAÇÕES FINAIS}

A regulação estatal é justificada para corrigir os efeitos nocivos das falhas do mercado (assimetrias informacionais, externalidades negativas, insuficiência de bens públicos, competências insuficientes) e das falhas de governo (entre todas, a teoria da captura).

No Brasil, ela teve como objeto principal a redução da máquina estatal, com a subsequente redução dos seus custos. Hodiernamente, vê-se um direcionamento ao estímulo das atividades econômicas, o que se impõe diante dos desígnios da Constituição Econômica no sentido de se verem implementados os direitos fundamentais e uma série de interesses das mais variadas dimensões.

A regulação, então, por meio dos seus instrumentos, as agências reguladoras, deve buscar o equilíbrio dos sistema, corrigindo as falhas de governo e do mercado, de maneira a otimizar a economia, a torná-la mais eficiente, mais produtiva, para fazer frente aos custos das prestações civilizatórias incumbidas ao Estado.

82 Cf. NORTH, Douglass C. Op. cit., p. 28.

83 SUNDFELD, Carlos Ari. Fundamentos de direito público. 4. ed. 7. tiragem. São Paulo: Malheiros, 2006. p. 110. 
Nesse escopo, a regulação, dentro de uma perspectiva neoinstitucional, afigura-se como um importante instrumento de influência sobre o resultado econômico, podendo atuar ex ante, quando determina os custos de transação da economia, e ex post, quando corrige resultados ineficientes.

Assim sendo, propõe-se, diante das relatadas no presente artigo, que a regulação estatal seja pautada: por uma máxima transparência; por uma racionalidade administrativa material e procedimental, empiricamente direcionada e comprometida com o princípio da eficiência, principalmente no seu teor adaptativo; por uma relação dialogada e negocial com os três destinatários da atividade regulacional; por uma fundamentação multidisciplinar de suas decisões; pela internalização dos princípios constitucionais da prevenção e da precaução em suas relações; por uma análise em perspectiva dos efeitos futuros e sistêmicos da sua atividade, preocupando-se com a estabilidade do mercado; pela sindicabilidade ampla dos atos estatais; por uma internalização institucional dos seus problemas, como, por exemplo, pela regulamentação profunda do lobby; por uma adequada alocação de recursos, de forma a reduzir a incerteza por meio de uma gestão perene e dinâmica de acompanhamento dos resultados regulatórios, que propicie a correção das distorções encontradas a tempo e modo.

Assim, essas são as pautas que se entende devam orientar uma regulação institucionalmente adequada à maximização da eficiência do sistema econômico dentro de uma perspectiva social.

\section{REFERÊNCIAS}

ALMEIDA, Fernando Dias Menezes de. Teoria da regulação. In: CARDOZO, José Eduardo Martins; QUEIROZ, João Eduardo Lopes; SANTOS, Walquíria Batista dos Santos (Coord.). Direito administrativo econômico. São Paulo: Atlas, 2011.

ARAGÃO, Alexandre Santos de. Agências reguladoras: algumas perplexidades e desmistificações. Interesse Público, Rio de Janeiro: Fórum, a. 10, n. 51, set./out. 2008.

. Agências reguladoras e a evolução do direito administrativo econômico.

2. ed. Rio de Janeiro: Forense, 2009.

ARAúJO JúNIOR, Ari Francisco de. Microeconomia. In: TIMM, Luciano Benetti. Direito e economia no Brasil. São Paulo: Atlas, 2012.

ARROW, Kenneth. The organization of economic activity: issues pertinent to the choice of market versus non-market allocation. The analysis and evaluation of public expenditures. The PBB-System, Joint Economic Committee, $91^{\text {st }}$ Congress, $1^{\text {st }}$ session, v. 1. Government Printing Office: Washington, D.C., 1969, passim. 
CAMPOS, Humberto Alves de. Falhas de mercado e falhas de governo: uma revisão da literatura sobre regulação econômica. Prismas: Dir., Pol. Publ. e Mundial., Brasília, v. 5, n. 2, jul./dez. 2008.

CAVALCANTI, Francisco Queiroz Bezerra. A reserva de densificação normativa da lei para preservação do princípio da legalidade. In: BRANDÃO, Cláudio; CAVALCANTI, Francisco de Queiroz Bezerra; ADEODATO, João Maurício (Coord.). Princípio da legalidade: da dogmática jurídica à teoria do Direito. Rio de Janeiro: Forense, 2009.

. Reflexões sobre o papel do estado frente à atividade econômica. Revista Trimestral de Direito Público, n. 20, 1997.

CHEVALLIER, Jacques. Science administrative. 2 édition refondue. Paris: PUF, 1994.

CUÉLLAR, Leila. As agências reguladoras e seu poder normativo. São Paulo: Dialética, 2001.

CYRINO, André Rodrigues. Direito constitucional regulatório: elementos para uma interpretação institucionalmente adequada da Constituição Econômica brasileira. Rio de Janeiro: Renovar, 2010.

COASE, Ronald H. The nature of the firm. New Series, v. 4, n. 16, nov. 1937. . The problem of social cost. Journal of Law and Economics, 1960, passim.

DI PIETRO, Maria Sylvia Zenella. Direito administrativo. 25. ed. São Paulo: Malheiros, 2012. . Parcerias na Administração Pública. 3. ed. São Paulo: Atlas, 1999.

FABRI, Andréa Queiroz. A contradição entre a concessão administrativa em monopólio e o direito de acesso aos mercados: desafios para a regulação e para os direitos dos usuários dos serviços públicos. Revista de Direito Público da Economia - RDPE, Belo Horizonte, a. 6, n. 23, jul./set. 2008.

FERRAZ JUNIOR, Tércio Sampaio. Como regular agências reguladoras? Revista Brasileira de Direito Público, Belo Horizonte, a. 6, n. 22, jul./set. 2008.

FREITAS, Juarez. Direito fundamental à boa administração publica e a constitucionalização das relações administrativas brasileiras. Interesse Público, Belo Horizonte, a. 12, n. 60, mar./abr. 2010.

GALDINO, Flávio. Introdução à teoria dos custos dos direitos. Direitos não nascem em árvores. Rio de Janeiro: Lumen Juris, 2005.

GARCIA, Maria da Glória F. P. D. Direito das políticas públicas. Coimbra: Almedina, 2009.

GRAU, Eros Roberto. A ordem econômica na Constituição de 1988 (interpretação e crítica). 15. ed. rev. e atual. São Paulo: Malheiros, 2012. 
GENTOT, Michel. Les Autorites administratives independants. 2. ed. Paris: Montcherestien, 1994.

HOLMES, Stephen; SUNSTEIN, Cass. The cost of rights: why liberty depends on taxes. New York: W. W. Norton \& Co., 1999.

JUSTEN FILHO, Marçal. O direito das agências reguladoras independentes. São Paulo: Dialética, 2002.

KRELL, Andreas Joachin. Discricionariedade administrativa e proteção ambiental: o controle dos conceitos jurídicos indeterminados e as competências dos órgãos ambientais. Um estudo comparativo. Porto Alegre: Livraria do Advogado, 2004.

LISBOA, Marcos. Instituições e crescimento econômico. In: BACHA, E.; BOLLE, M. (Org.). Novos dilemas da política econômica: ensaios em homenagem a Dionísio Dias Carneiro. Rio de Janeiro: Casa das Garças/LTC, 2011.

MARCOU, Gérard. La regulación y los servicios públicos. Las enseñanzas del derecho comparado. In: MARCOU, Gerard; MODERNE, Frank (Directores). Derecho de la regulación, los servicios públicos y la integración regional. t. I. Bogotá: Editorial Universidad del Rosario, 2009.

MARQUES NETO, Floriano Azevedo. A nova regulação estatal e as agências independentes. In: SUNDFELD, Carlos Ari (Coord.). Direito administrativo econômico. 3. tiragem. São Paulo: Malheiros, 2006.

MOREIRA, Egon Bockmann. O direito administrativo da economia, a ponderação de interesses e o paradigma da intervenção sensata. In: CUÉLLAR, Leila; MOREIRA, Egon Bockmann. Estudos de direito econômico. Belo Horizonte: Fórum, 2004.

; GUIMARÃES, Fernando Vernalha. A Lei Geral de Licitação - LGL e o Regime Diferenciado de Contratação - RDC. 4. ed. rev. e aum. São Paulo: Malheiros, 2012.

MOREIRA NETO, Diogo de Figueiredo. Direito regulatório. Rio de Janeiro: Renovar, 2003.

MOREIRA, Vital. Auto-regulação profissional e Administração Pública. Coimbra: Livraria Almedina, 1997.

NÓBREGA, Marcos. Direito da infraestrutura. São Paulo: Quartier Latin, 2011.

NORTH, Douglass C. Desempenho econômico através do tempo. Tradução de Antonio José Maristrello Porto. Revista de Direito Administrativo, Rio de Janeiro: FGV, v. 255, set./dez. 2010.

NUNES, Edson. Agências regulatórias: gênese, contexto, perspectivas e controle. Revista de Direito Público da Economia - RDPE, Belo Horizonte, n. 2, abr./jun. 2003. 
ORTEGA, Ricardo Rivero. Nociones generales sobre derecho administrativo económico. In: CARDOZO, José Eduardo Martins; QUEIROZ, João Eduardo Lopes; SANTOS, Walquíria Batista dos Santos (Coord.). Direito administrativo econômico. São Paulo: Atlas, 2011.

ORTIZ, Gaspar Ariño Ortiz. Princípios de derecho público económico. Granada: Comares e Fundación de Estudios de Regulación, 1999.

PONTES DE MIRANDA. Comentários à Constituição de 1967 com a Emenda no 1 de 1969. 2. ed. São Paulo: Revista dos Tribunais, t. III, 1970.

POSNER, Richard A. Theories of economic regulation. [S.I.]: NBER, 1974. (Working paper, n. 41).

RAVINA, Carlos Morales de Setién; POSNER, Richard A.; LANDES, William M.; KELMAN, Mark G. Análisis Económico del derecho. Bogotá: Siglo del Hombre Editores; Universidad de los Andes; Pontificia Universidad Javeriana-Instituto Pensar, 2011.

SILVA FILHO, Edison Benedito da. A teoria da firma e a abordagem dos custos de transação: elementos para uma crítica institucionalista. Pesquisa \& Debate, São Paulo, v. 17, n. 2 (30), 2006.

STIGLER, George J. The theory of economic regulation. The Bell Journal of Economics and Management Science, v. 2, n. 1, Spring, 1971.

SOUSA, Marcelo Rebelo de; MATOS, André Salgado de. Direito administrativo geral: introdução e princípios fundamentais. 3. ed. reimp. Alfragide: Dom Quixote, t. I, 2010.

SUNDFELD, Carlos Ari. Fundamentos de direito público. 4. ed. 7. tiragem. São Paulo: Malheiros, 2006. . Introdução às agências reguladoras. In: SUNDFELD, Carlos Ari (Coord.). Direito administrativo econômico. 3. tiragem. São Paulo: Malheiros, 2006. SUNSTEIN, Cass. Paradoxes of the regulatory state. The University of Chicago Law Review, v. 57, n. 2, Administering the Administrative State, 1990.

TAVARES, André Ramos. A intervenção do Estado no domínio econômico. In: CARDOZO, José Eduardo Martins; QUEIROZ, João Eduardo Lopes; SANTOS, Walquíria Batista dos Santos (Coord.). Direito administrativo econômico. São Paulo: Atlas, 2011.

Direito constitucional econômico. São Paulo: Método, 2003.

VIANNA, Salvador Teixeira Werneck. Desenvolvimento econômico e reformas institucionais no Brasil: considerações sobre a construção interrompida. Tese de doutorado. Rio de Janeiro: Instituto de Economia, Universidade Federal do Rio de Janeiro, 2007. 
WILLIAMSON, Oliver E. Why Law, Economics and Organization? December 2000. UC Berkeley Public Law Research, Paper n. 37. Disponível em: <http://ssrn. com/abstract=255624>. Acesso em: 8 jul. 2012, p. 7.

ZIPPELIUS, Reinhold. Teoria geral do Estado. Tradução de Karin Praefke-Aires Coutinho, Coordenação de J. J. Gomes Canotilho. 3. ed. Lisboa: Fundação Calouste Gulbenkian, 1997. 